\title{
Industry 4.0 Future Managerial Challenges for Pakistani Markets/Industries
}

\author{
Habibullah \\ Karachi university business school. \\ Dr.Muhammad Asim \\ Karachi university business school. \\ Salmam Manzoor \\ Karachi university business school
}

\begin{abstract}
Industrial revolution 4.0 is the term used by German scientist. The concept of industrial 4.0 is artificial Intelligence, smart factories, internet of things, cyber physical system. Industrial revolution 4.0 is a technological advancement of current era. The main purpose of this paper is to find barriers, challenges to implementation in Pakistan. Industrial revolution 4.0 future managerial and technological challenges for Pakistani industries and market. Pakistani industry has lack of experience of management in context of industrial revolution 4.0 and Pakistani industry needs competitive management in context of industry 4.0. Human Resources management plays a vital role through training Programs and jointly works with engineering universities and business universities to overcome challenges more efficiently. Pakistan's Infrastructure, economic condition, instability, utility crisis, unavailability of smart devices, and unavailability of latest machinery may also be possible barriers. Conducting an online survey through questionnaire may highlight the underlying causes for this issue.
\end{abstract}

Keywords Pakistan, industry 4.0, artificial intelligence, smart factories, managerial challenges, Human resource management, training.

DOI: $10.7176 / \mathrm{EJBM} / 12-3-02$

Publication date: January $31^{\text {st }} 2020$

\section{Introduction of Industry 4.0:}

Industry 4.0 is a new concept develop by German scientists it is totally new concept of production combination with cyber physical system(CPS), Internet of things(IOT), artificial intelligence(AT), Internet of service(IOS) are given new concept of industries like Smart factories, smart manufacturing, smart production, smart operations, etc. Industry 4.0 is an economical \& beneficial for an industry and a country to improve economic growth rates. Industry 4.0 improve production process during manufacturing and reduce the product cost, product time to consume it to make it and made easily flexible to change the product ultimately benefit for organization to provide customer low cost product and increase market share and improve lead time. The first industrial revelation starts from England in 1780s it starts from introduce to water power and steam engine and mechanical production and improving agriculture sector. The second industrial revolution starts from 1870s from electric power and assembly line, concept of mass production and third revolution starts from 1969 from integrated with first time programmable logistic control (PLC), application of electronics and information of Communication Technology (ICT) with computers to start first time automate production. The journey started from England and is still ongoing, Germany gave it new name industries 4.0 in (2013) and it integrated with IT and electronic, many countries are working on industry 4.0 and have made strategic level policies. Germany is working on it from 2013 in which they introduced artificial intelligence in factories and machines are able to communicate with each other automatically without any required human interfere and also check quality of some aspect of product automatically like weight. German government is trying to complete it in 2020 and working on it given name "Industries 4.0". USA is launching it with another name called "Industrial internet consortium (IIC)" founded in 2014 with help of GE, AT \& T, Cisco, Intel and IBM to provide resources and idea of "Industrial Internet of Things (IIOT)".In China working on other name called "Made in China 2025" initiative take by ministry of industry and information technology. In Korea the term industry 4.0 used widely and Korean Government take many initiatives and Thailand government is also working and finding Gap for implementations. Pakistan has not defined its Strategic policies for industry resolution 4.0 but nowadays we can hear the word digitalized "Government". 


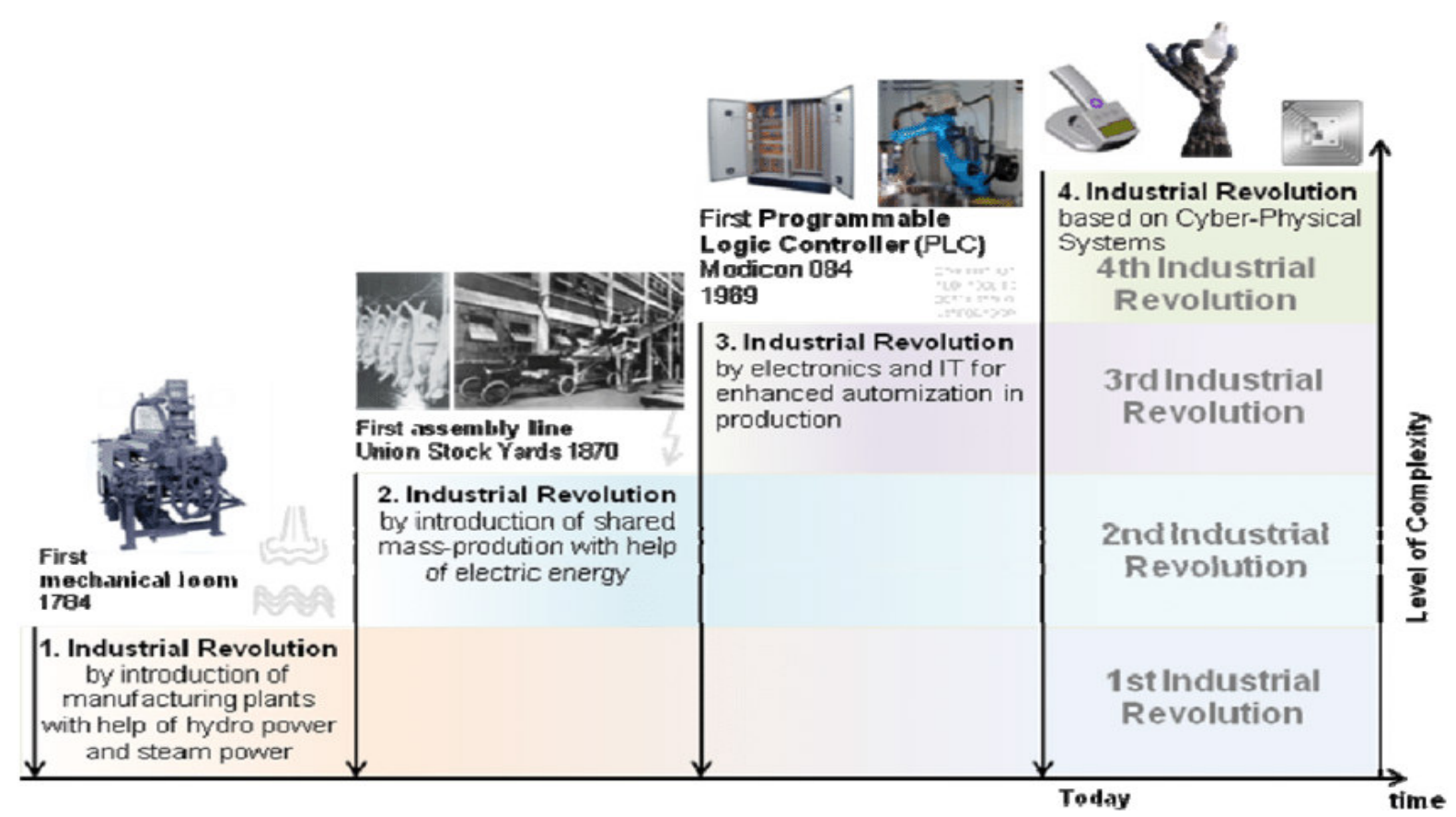

Figure 1 Industrial Revolution.

\subsection{Definition of Industry 4.0:}

Industry 4.0 is not defined clearly but some author's definitions are here to understand of industrial revolution 4.0. 1-Industry 4.0 utilizing the power of communications technology and innovative inventions to boost the development of the manufacturing industry. (Kagermann, Wahlster \& Johannes. (2013). [1] 2-Industry 4.0 encourages manufacturing efficiency by collecting data smartly, making correct decisions and executing decisions without any doubts. By using the most advanced technologies, the procedures of collecting and interpreting data will be easier. The interoperability operating ability acts as a 'connecting bridge' to provide a reliable manufacturing environment in Industry 4.0. This overall consciousness gives Industry 4.0 the most important aspect of artificial intelligent functions. ( Qin, Liu \& Grosvenor (2016). [1]

3-Industry 4.0 is surrounded by a huge network of advanced technologies across the value-chain. Service, Automation, Artificial Intelligence Robotics, Internet of Things and Additive Manufacturing are bringing in a brand new era of manufacturing processes. The boundaries between the real world and virtual reality is getting blurrier and causing a phenomenon known as Cyber-Physical Production Systems (CPPS).( Schumacher, Erol \& Sihn, (2016). [1]

4-Industry 4.0 is differentiated by a few characteristics of new technologies, for example: physical, digital, and biological worlds. The improvement in technologies is bringing significant effects on industries, economies and governments' development plans. Schwab pointed out that Industry 4.0 is one of the most important concepts in the development of global industry and the world economy. (Schwab (2016). [1] 5-Industry 4.0 makes full use of emerging technologies and rapid development of machines and tools to cope with global challenges in order to improve industry levels. The main concept of Industry 4.0 is to utilize the advanced information technology to deploy (IoS) services. Production can run faster and smoothly with minimum downtime by integrating engineering knowledge. Therefore, the product built will be of better quality, production systems are more efficient, easier to maintain and achieve cost savings. (Wang et al., (2016). [1]

The modern and more sophisticated machines and tools with advanced software and 6-networked sensors can be used to plan, predict, adjust and control the societal outcome and business models to create another phase of value chain organization and it can be managed throughout the whole cycle of a product. Thus, Industry 4.0 is an advantage to stay competitive in any industry. To create a more dynamic flow of production, optimization of value chain has to be autonomously controlled. (Mrugalska \& Magdalena (2017). [1]

\subsection{Internet of Things (IOT);}

The ability of communicate machines, sensors peoples and control through internet is called internet of things (IOT) or also called Internet of People (IOP.) 


\subsection{Artificial Intelligence (AI):}

Merriam-Webster defines artificial intelligence this way:

A branch of computer science dealing with the simulation of intelligent behavior in computers.

The capability of a machine to imitate intelligent human behavior. [2].

\subsection{Smart Factories:}

The smart factories is a concept of digitization and contacted environment to improve the all production process to connected with via internet of things to communicate to machine each other to improve physical production goods and function like planning, supply chain and logistics and the investment to building smart factory to provide safe, efficient, and more reliable product. Companies need to adopt digital technologies to meet customer Expectations. According to some sources, Industry 4.0 factory could result in decrease of

Production costs by $10-30 \%$,

Logistic costs by $10-30 \%$,

Quality management costs by $10-20 \%$

\subsection{Cyber Physical System (CPS):}

Physical and engineered systems whose operations are monitored, controlled, coordinated, and integrated by a computing and communicating core" (Rajkumar et al. 2010). The interaction between the physical and cyber elements is of key importance: "CPS is about the intersection, not the union, of the physical and the cyber. It is not sufficient to separately understand the physical components and the computational components. We must understand their interaction" (Lee and Seshia 2014). [4].

\section{Pakistan}

A country full of talent and world fifth largest population and seventh atomics power situated a strategical location, included top most fifth intelligent nation in the world, top seventh happiest country, neighbor countries are china, India, (half of world population) Iran and Afghanistan. Have a sea port, 4 beautiful weathers and then as a nation Pakistan living second era of industrial revolution it is a big setback for Pakistan as nation and no role in world economic. Pakistan's biggest problem is lack of visionary leadership. Instability, corruption, terrorism, utility crisis, unbalance infrastructure for industry. Unfortunately, Pakistan during 2005 to still under terrorist attacks and it badly damaged Pakistani economic, infrastructure, industries and also many industries shift to other countries like Bangladesh, India and other countries. CPEC is chance to Pakistan to develop it infrastructure, utility crisis because china invests in Pakistan around 70 billion dollars in energy sector, infrastructure. Gawader port. Pakistan need to joint work for industry 4.0 with china in defense sector they jointly made Jf 17 project and made a state-of-the-art fighter jet and now working on exports. Pakistani industry has chance to gained experience to work on industry 4.0 to improve it economic conditions. Recently Pakistani government take step to digitized Pakistan and hire Google executive from Malaysia.

\subsection{Infrastructure:}

Pakistan's infrastructure is badly damaged by terrorist attacks from 2005 to 2016 and now Pakistan is trying to develop the infrastructure to sign CPEC with china project called one belt one road during survey from industries plant head, senior managers, managers, assistant managers, and engineers to ask question "Pakistan's infrastructure in context for IR.4.0" the following result found.

1. $3.6 \%$ say very good.

2. $22.9 \%$ say good.

3. $33.7 \%$ say Fair/ Average

4. $33.7 \%$ say poor.

5. $6 \%$ Say very Poor.

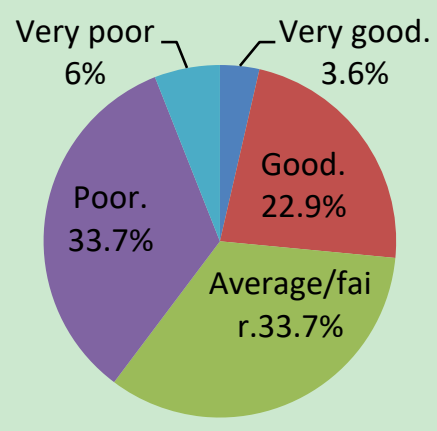

The above survey conducts Pakistan and world renowned companies and found result Pakistan need to improve it infrastructure. 


\subsection{Economy:}

Instability has directly affected Pakistan's economy and Pakistan gone to defaulter in this stage Sudia Arabia, UAE, and China Support Pakistan economy. And Pakistani government is taking steps to improve economy. Now while writing this thesis Pakistani economy is in better position. Therefore included question related to economy was "Pakistan's economy condition is barrier for IR 4.0" following result found

1. $16.9 \%$ say strongly agree.

2. $26.5 \%$ say agree

3. $36.1 \%$ say undecided.

4. $15.7 \%$ say disagree.

5. $4.8 \%$ say strongly disagree.

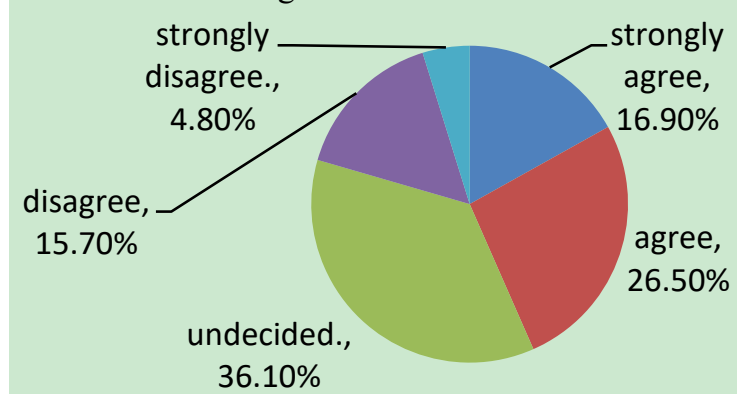

The above survey says Pakistan need to improve it economy.

\subsection{UTILITY CRISIS:}

Many attacks on Pakistan Gas pipes, Electric powers generation, and electric load shedding, resulted in increase in electricity price, many Pakistani industries shuffle from Pakistan to other countries therefore add a question what are the thinking of industries top to lower employee's question was "One of the big barrier is utility (energy) crisis" and fond result are following

1. $12 \%$ say Strongly Agree.

2. $43.4 \%$ say Agree.

3. $21.7 \%$ say undecided.

4. $15.7 \%$ say disagree.

5. $7.2 \%$ say strongly disagree.

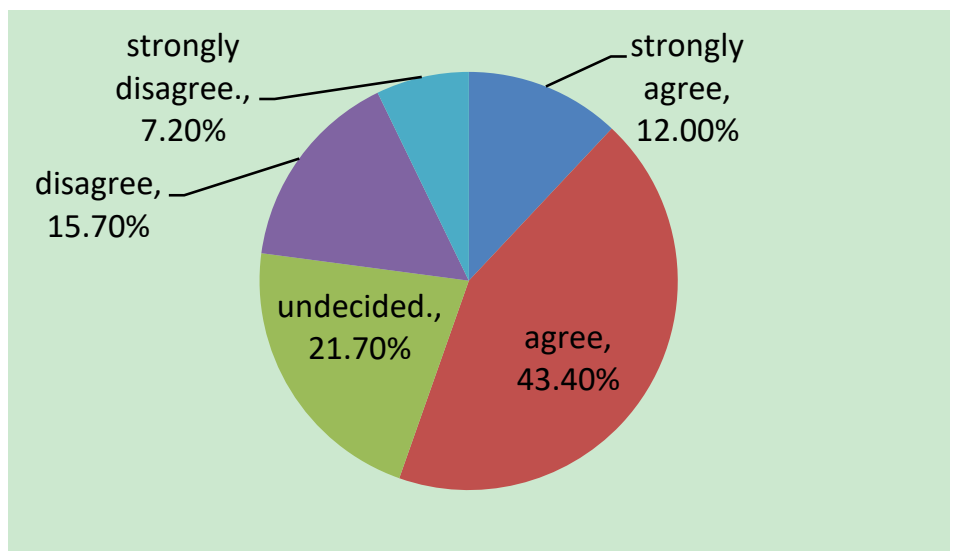

Pakistan and china made agreement on CPEC, china invested in Pakistan energy sector and in recent years many project will be completed and few will be completed in near future and will lower price of electricity to improve Pakistan industrial sector.

\subsection{Education:}

Pakistani universities upgraded their course and converted it to latest world develop countries' universities or compare with them and educated them latest technology in practical way for overcome challenges to new era of technology and Pakistani industry will adopt fast there also papered two questions for universities' student and younger engineer's first question is "Your familiarity with IR 4.0? "And result is

1. $11.9 \%$ say very good.

2. $28.6 \%$ say good.

3. $35.7 \%$ say average/fair.

4. $16.7 \%$ say poor.

5. $7.1 \%$ say very poor.

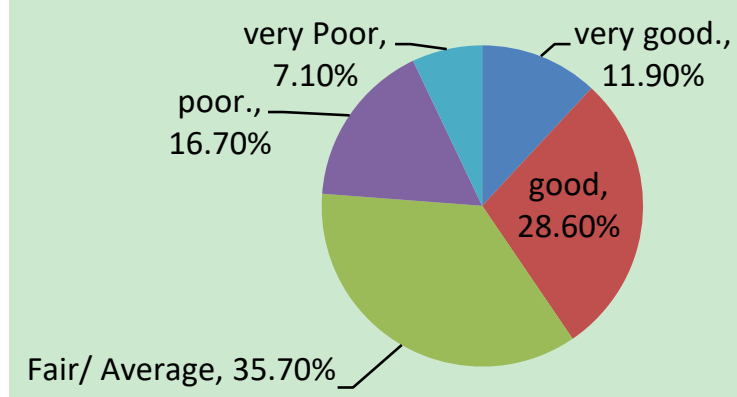


And second Question is "Your Knowledge about IR 4.0" and result is

1. $10.1 \%$ say very good.

2. $32.1 \%$ say good.

3. $34.5 \%$ say average/fair.

4. $14.3 \%$ say poor.

5. $8.3 \%$ say very poor.

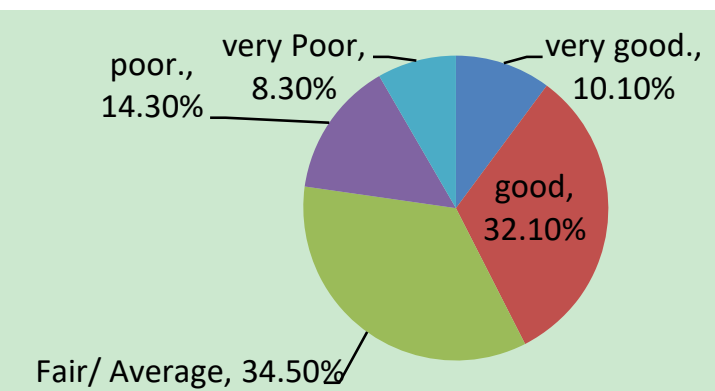

Fair/ Average, 34.50\%

The above result shows that Pakistan need to improve education system more and made an industrial park for student for future challenges.

\section{Pakistani Industries/Markets:}

Pakistan have textile industries ,process industries, electronic ,and other Pakistani industries still living in the second era of industrial revolution and facing many challenges like shortage of electricity, gas shortage, exchange rate problem, unavailability of latest equipment. Sialkot industries famous across the world for his sports, wooden and medical equipment. The industries, however, have failed due to not upgrading timely and taking benefit of competitor to improve techniques. Pakistani industries are still unprepared for industrial revolution 4.0 and ask some general question from employees and management. Questions and result are following.

"Your Company's R\& D for IR 4.0."

1. $4.8 \%$ say very good.

2. $19 \%$ say good.

3. $31 \%$ say Average.

4. $24.7 \%$ say poor.

5. $17.9 \%$ say very poor.
"Environment of IR 4.0".

1. $9.5 \%$ say very good.

2. $27.4 \%$ say good.

3. $36.7 \%$ say Average

4. $19 \%$ say poor.

5. $7.1 \%$ say very poor.
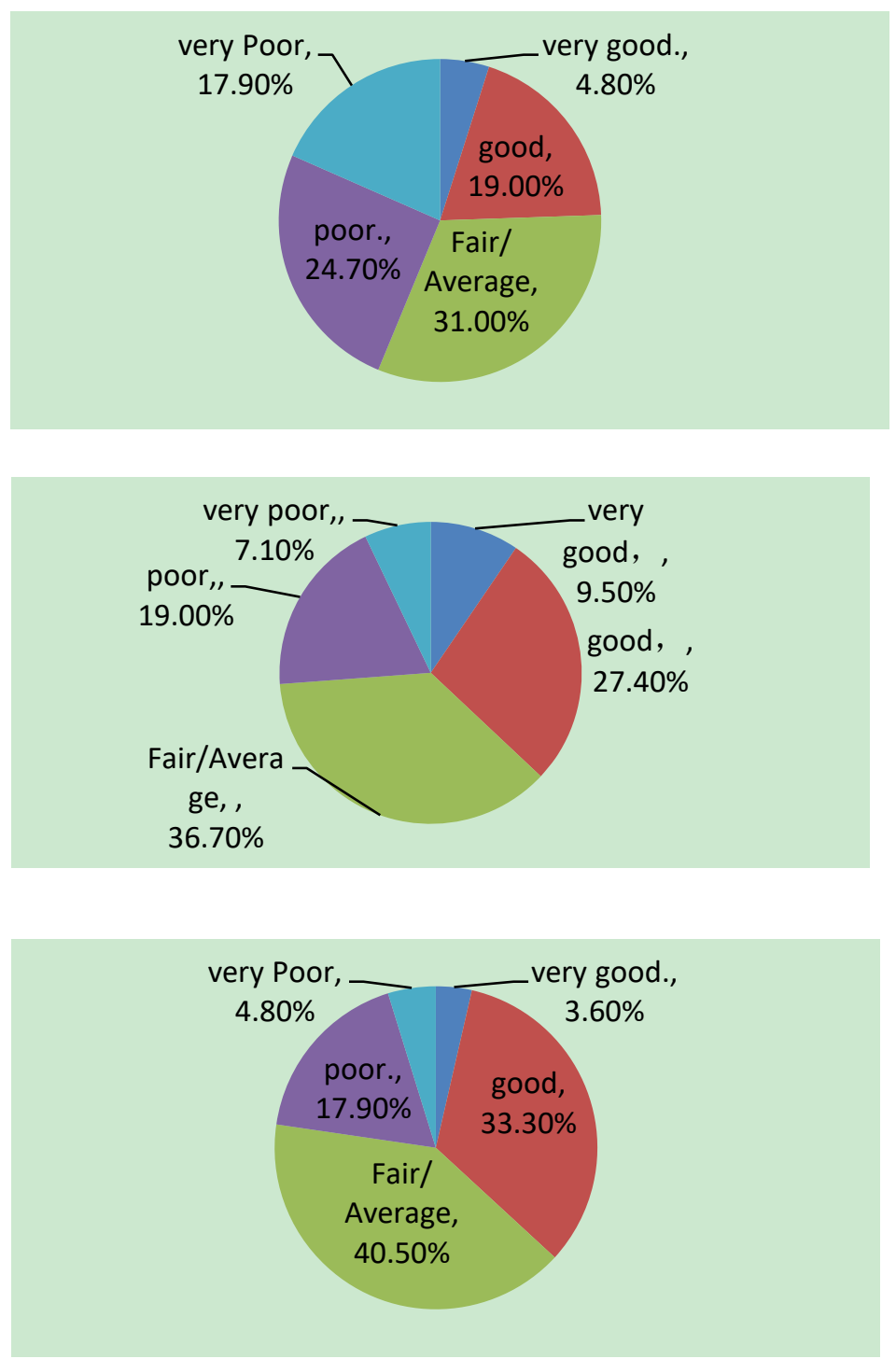
"Production system of IR 4.0".

1. $14.3 \%$ say very good.

2. $33.3 \%$ say good.

3. 23.8 say Average.

4. $21.4 \%$ say poor.

5. $7.1 \%$ say very poor.

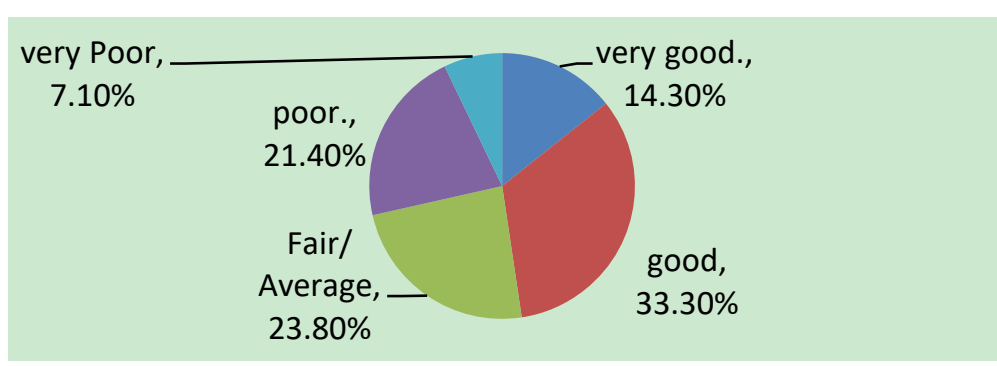

"Level of implementation of IR 4.0 in your company."

1. $2.4 \%$ say Very good.

2. $23.5 \%$ say Good

3. $41.2 \%$ say Average/fair.

4. $23.5 \%$ say Poor.

5. $9.4 \%$ say Very poor.

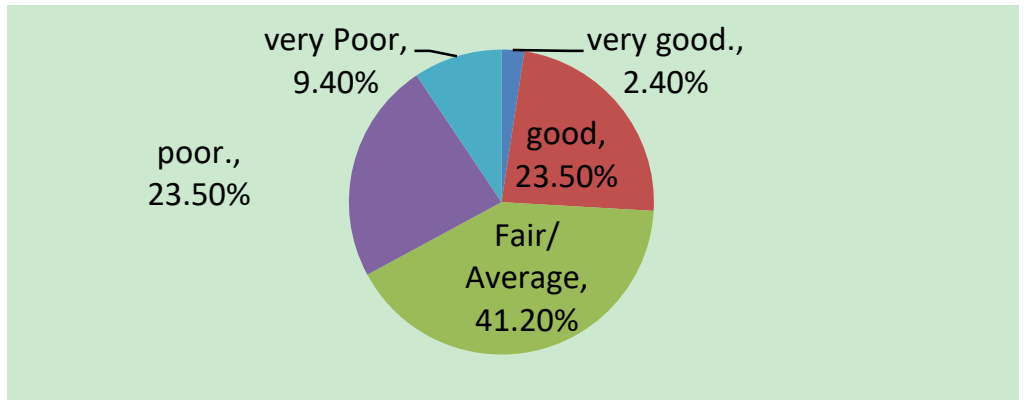

"Your Knowledge related to automation system of IR 4.0".

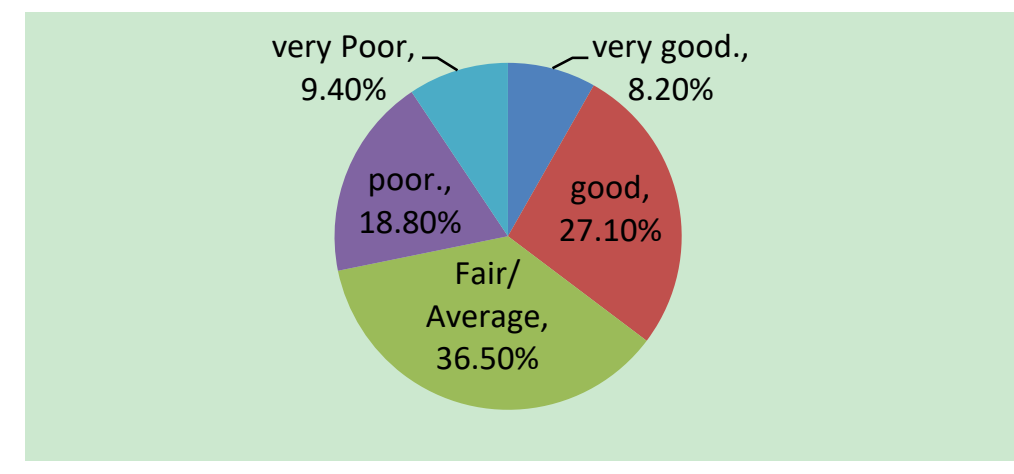

"IR 4.0 impact on production".

1. $14.1 \%$ say Very good.

2. $43.5 \%$ say good.

3. $25.9 \%$ say Average/fair.

4. $10.6 \%$ say Poor.

5. $5.9 \%$ say Very poor.

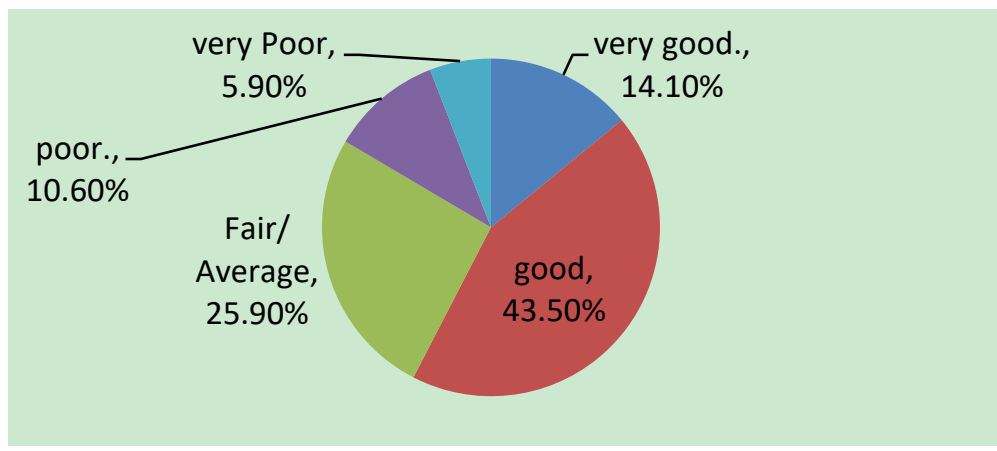


“IR 4.0's impact on company's revenue".

1. $15.3 \%$ say Very Good.

2. $44.7 \%$ say Good.

3. $24.7 \%$ say Average/fair.

4. $10.6 \%$ say Poor

5. $4.7 \%$ say Very poor.

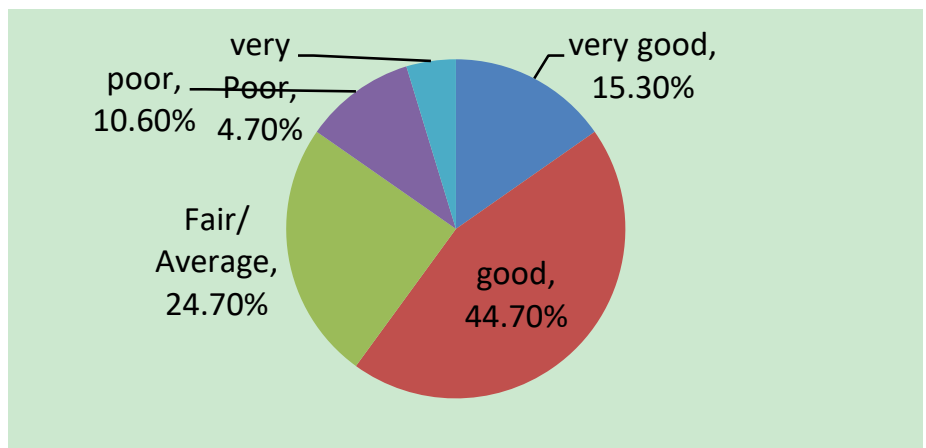

"Flexibility time of Product (Product Changing time)".

1. $10.6 \%$ say Very good.

2. $44.7 \%$ say Good.

3. $32.9 \%$ say Average/fair.

4. $8.2 \%$ say Poor.

5. $3.5 \%$ say Very poor.

"Maintenance of equipment".

1. $20 \%$ say Very good.

2. $40 \%$ say good.

3. $28.2 \%$ say Average/fair.

4. $8.2 \%$ say Poor.

5. $3.5 \%$ say Very poor.
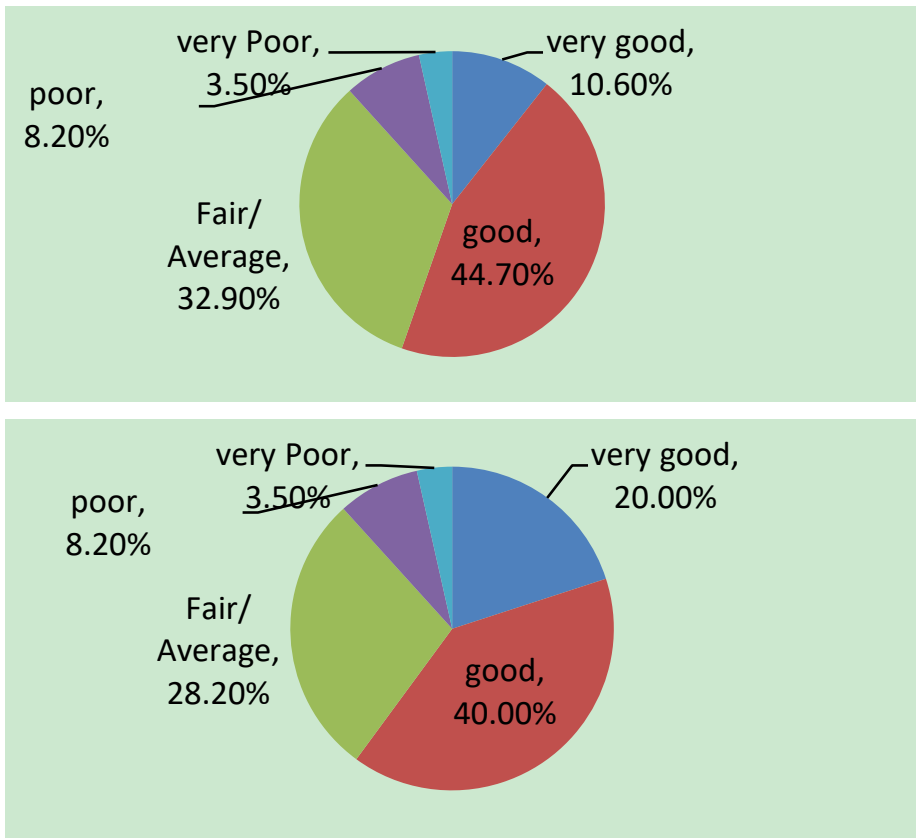

“Your Company's data recording \& recovery system”.

6. $10.6 \%$ say Very good.

7. $37.6 \%$ say Good.

8. $29.4 \%$ say Average/fair.

9. $17.6 \%$ say Poor.

10. $4.7 \%$ say Very poor.

11.

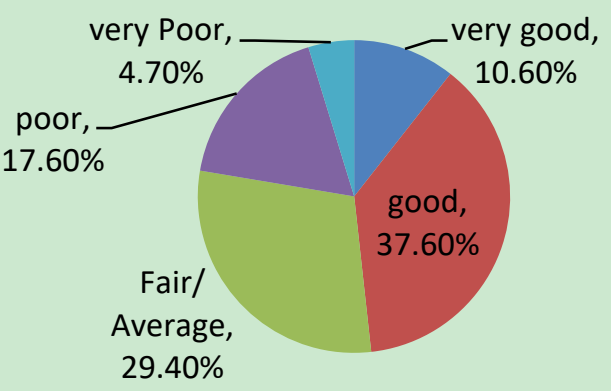

"Your knowledge about artificial intelligence".

12. $4.7 \%$ say Very good.

13. $40 \%$ say Good.

14. $35.3 \%$ say Average/Fair.

15. $14.1 \%$ say Poor.

16. $5.9 \%$ say Very poor.

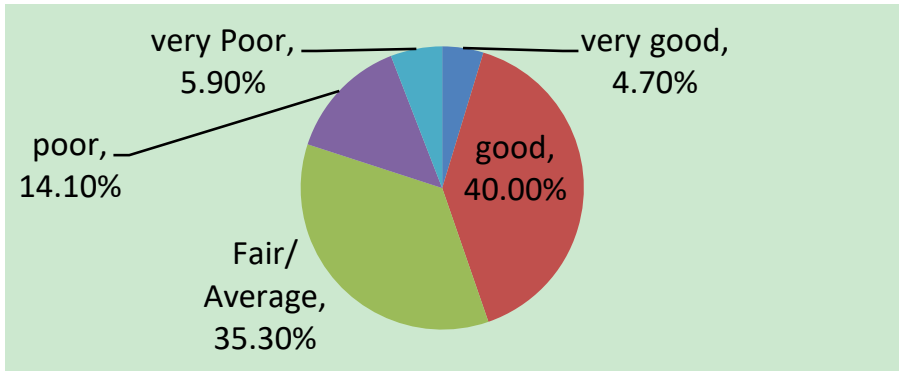


"Increase in productivity".

17. $16.5 \%$ say Very good.

18. $49.4 \%$ say Good.

19. $20 \%$ say Average/fair.

20. $9.4 \%$ say Poor.

21. $4.7 \%$ say Very poor.

"Decrease downtime".

1. $11.8 \%$ say Very good.

2. $41.2 \%$ say Good.

3. $34.1 \%$ say Average/fair.

4. $7.1 \%$ say Poor.

5. $5.9 \%$ say Very poor.

"Unemployment rate will increase"

1. $12.9 \%$ say strongly agree.

2. $37.6 \%$ say agree.

3. $31.8 \%$ say undecided.

4. $12.9 \%$ say disagree.

5. $4.7 \%$ say strongly disagree.

"Change in life style".

1. $14.1 \%$ say strongly agree.

2. $50.6 \%$ say agree

3. $24.7 \%$ say undecided.

4. $8.2 \%$ say disagree.

5. $2.4 \%$ say strongly disagree.
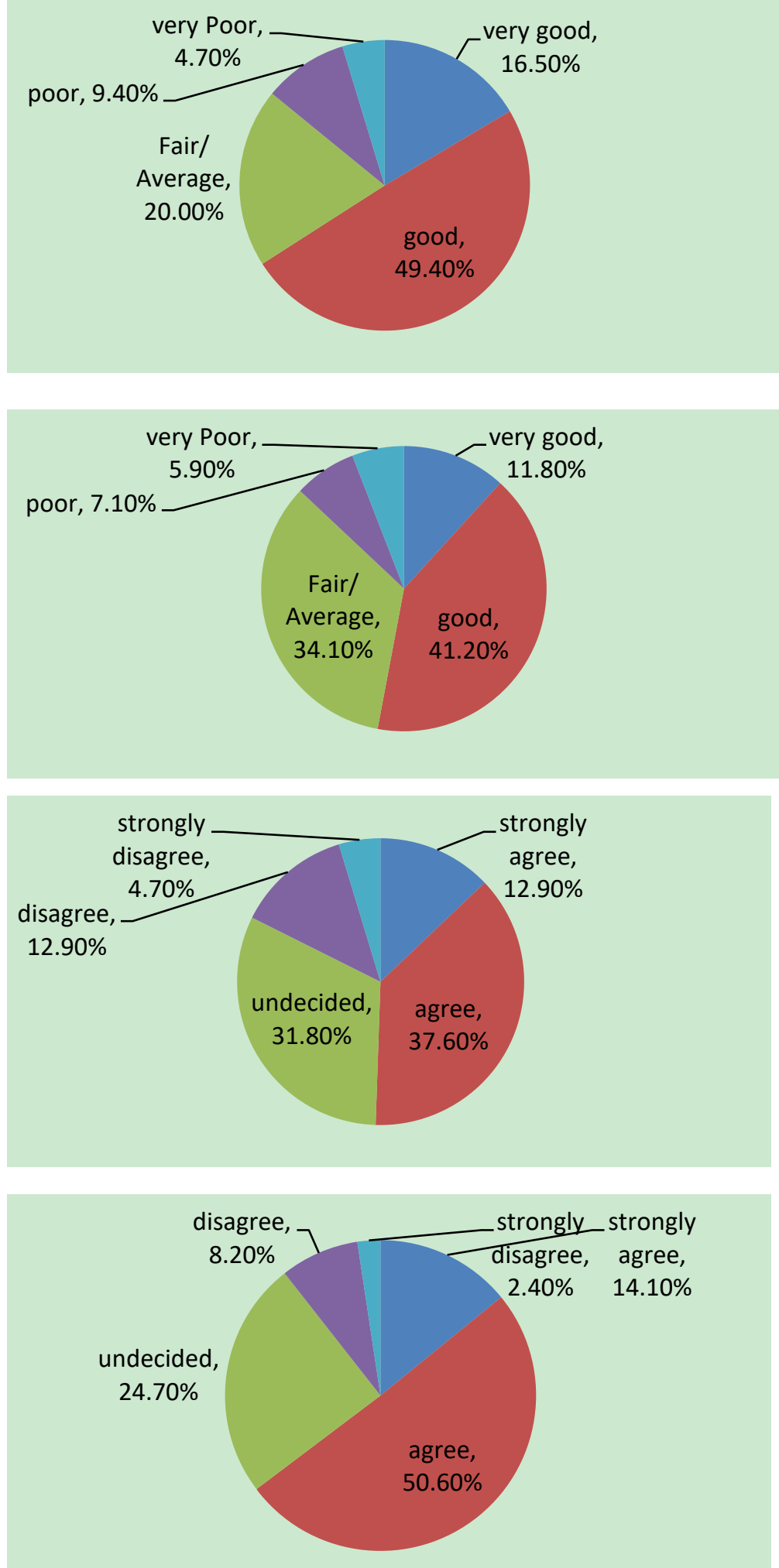
"Pakistani Industries/markets ready for IR 4.0".

1. $9.4 \%$ say strongly agree.

2. $21.2 \%$ say Agree.

3. $34.1 \%$ ay undecided.

4. $28.2 \%$ say disagree.

5. $7.1 \%$ say strongly disagree.

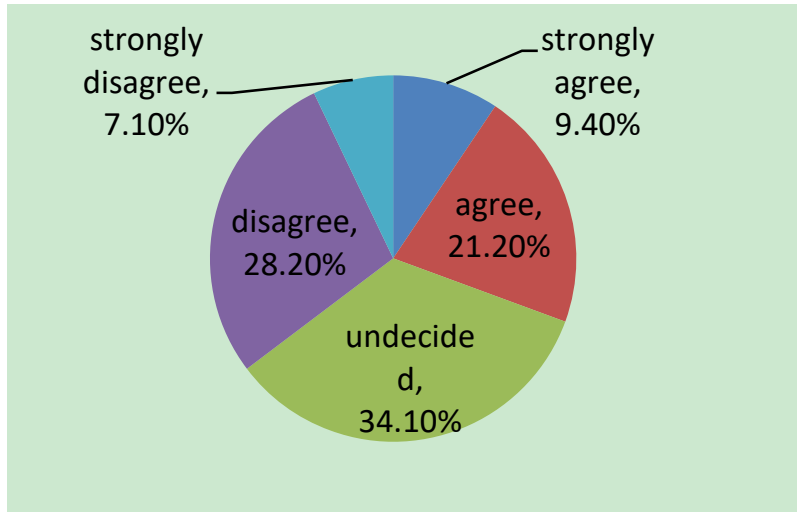

“Implementation of IR 4.0 Pakistan's economy growth rate will improve rapidly".

1. $16.5 \%$ say strongly agree.

2. $37.6 \%$ say agree.

3. $34.1 \%$ say undecided.

4. $8.2 \%$ say disagree.

5. $3.5 \%$ say strongly agree.

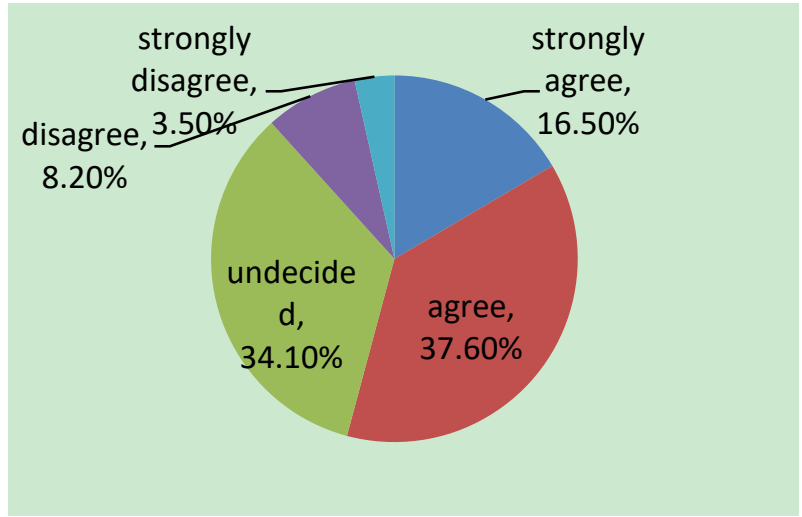

Unavailability of Technology like Smart Devices, and other latest machinery.

1. $16.5 \%$ say strongly agree.

2. $37.6 \%$ say agree.

3. $32.1 \%$ say undecided.

4. $8.2 \%$ say disagree.

5. $4.7 \%$ say strongly agree

\subsection{Lack of Experience:}

The main reason that Pakistani industry not develop because it still living in second era and it is a comfort zone for old Experience and strategic management therefore they do not upgrade themselves and as a result they have no experience of third era and some are not familiar with industry 4.0 during research questionnaire result are here and also question mention following "Your company's management in context of IR 4.0".

1. $7.1 \%$ say very good.

2. $21.4 \%$ say good.

3. $28.6 \%$ say Average.

4. $29.8 \%$ say poor.

5. $13.1 \%$ say very poor.
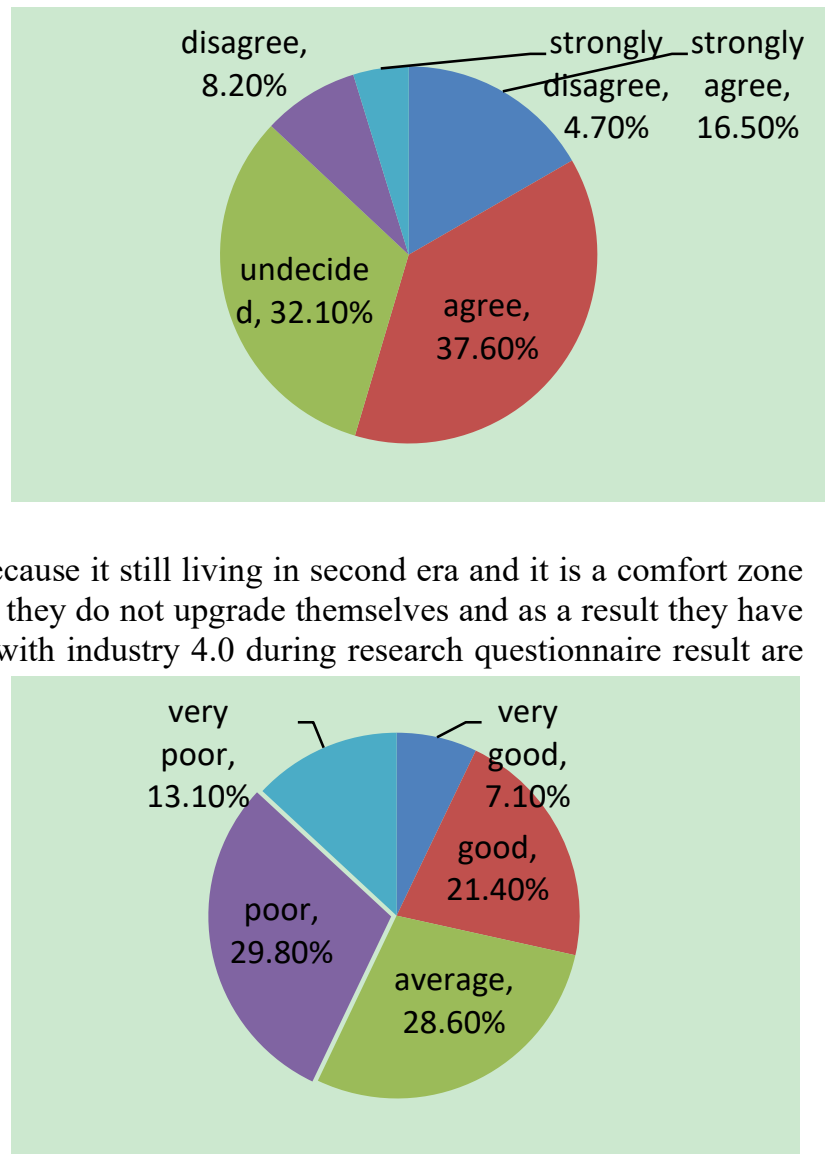
Lack of experience in managerial skills in context of IR 4.0

1. $11.8 \%$ say strongly agree.

2. $41.2 \%$ say Agree.

3. $30.6 \%$ say undecided.

4. $12.9 \%$ say disagree

5. $3.5 \%$ say strongly disagree

\subsection{Competitive Management:}

Pakistani industry need competitive management to overcome futures industrial challenges and adoption of new era of industrial revolution during survey found following.

"Future's big challenge for management."

1. $22.4 \%$ say strongly agree.

2. $38.8 \%$ say Agree.

3. $27.1 \%$ say undecided.

4. $10.6 \%$ say disagree

5. $1.2 \%$ say strongly disagree

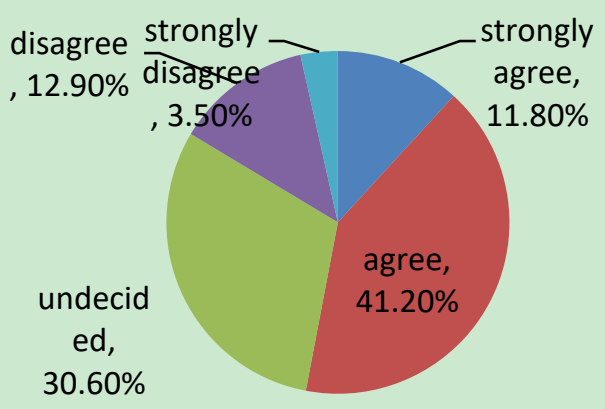

"Need Competitive Management".

6. $27.4 \%$ say strongly agree.

7. $38.1 \%$ say Agree.

8. $23.8 \%$ say undecided.

9. $9.5 \%$ say disagree

10. $1.2 \%$ say strongly disagree.

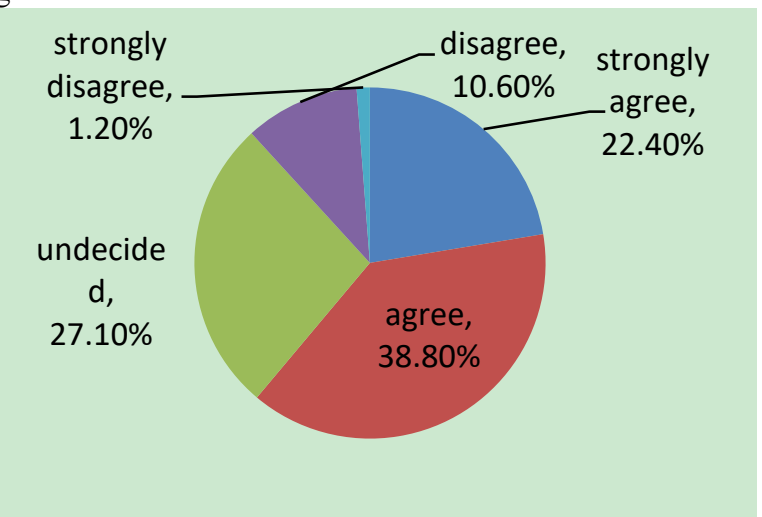

\subsection{Industries Human Resource:}

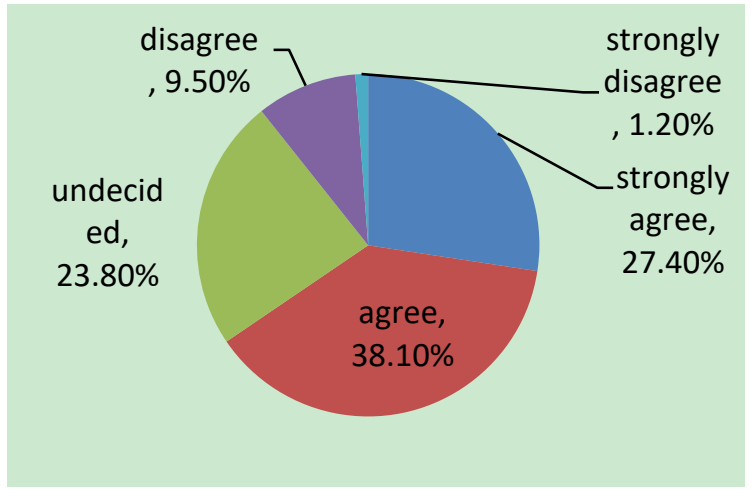

Human resource management is one of the key department of any industry it is responsible to arrange Capable man power for industry and also manage the training of employees to updates latest techniques to made beneficial for company and face challenges of upcoming challenges. Nowadays, big challenge is industry 4.0 and Pakistani industries has lack of experience in management and also lack of experience in lower management for example engineers, technician due this human resource management need to take a strategic steps to work with universities to overcome futures big challenges. Human resource needs capable management top bottom level therefore they take advantages from engineering, and Business universities to made joint courses, training sections, facilitate student for research, giving him task to research, facility of fund because primary research is very expensive therefore made short term and long term policies to overcome the future challenges. The result of my survey defines as clear picture what is the thinking of employee's. My question was 
"HR Contribution in context of IR 4.0".

1. $8.2 \%$ say Very good.

2. $17.6 \%$ say Good.

3. $30.6 \%$ say Average/fair.

4. $31.8 \%$ say Poor.

5. $11.8 \%$ say Very poor.

6.

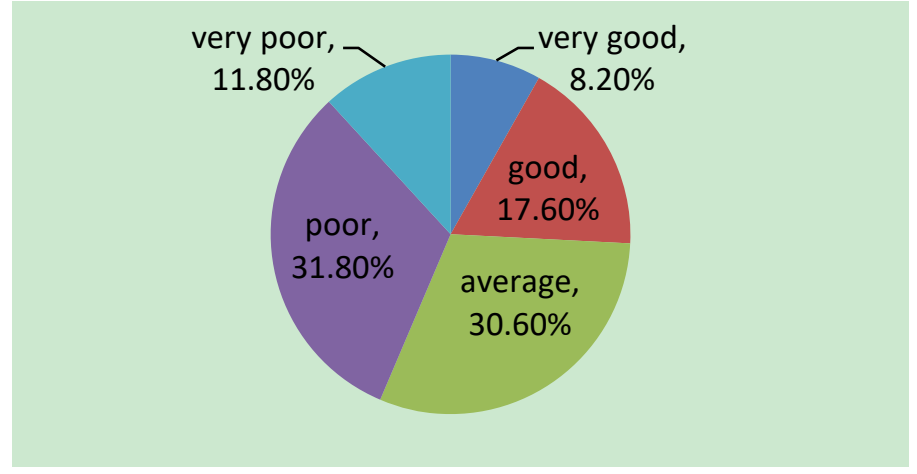

\section{Conclusion}

Pakistani policies maker have a chance to make a long and short and long term policy in context of industry 4.0 because most of world still working for industry 4.0 and some countries are capable of implementing it in near future and some countries like china also included therefore Pakistan can take experience from chain and try together like Defense sector. China is investing billions of dollars in Pakistan to improve infrastructures, energy sectors, oil and gas sectors, industrial zones and etc. Industrial zone made with those organizations working on industry 4.0 and in near future can convert all organization in smart factories concept. These organization will help to make infrastructure and create environment for industry 4.0 and on other side Pakistani government is taking steps to improve infrastructure, develop new power generation plant, working on gas issues and resolve all crisis to make environment for investment should also work on education sector like, engineering, and business universities to overcome upcoming managerial and technical advancement challenges and improve economic condition of Pakistan

\section{References}

1. https://www.researchgate.net/publication/332440369_An_Overview_of_Industry_40_Definition_Componen ts and_Government_Initiatives

2. https://www.forbes.com/sites/bernardmarr/2018/02/14/the-key-definitions-of-artificial-intelligence-ai-thatexplain-its-importance/\#532f100f4f5d

3. https://ottomotors.com/blog/what-is-the-smart-factory-manufacturing

4. https://link.springer.com/referenceworkentry/10.1007\%2F978-3-642-35950-7 16790-1

5. https://online-journals.org/index.php/i-jim/article/viewFile/7072/4532

6. https://www.indexmundi.com/pakistan/geography_profile.html

7. https://www.dawn.com/news/1507479

8. https://en.wikipedia.org/wiki/Economy_of Pakistan

9. https://en.wikipedia.org/wiki/Number_of_terrorist incidents_by_country

10. https://www.sciencedirect.com/science/article/pii/S0301421519300175

11. https://www.aljazeera.com/indepth/opinion/pakistan-economy-sinking-190628174320798.html

12. https://nation.com.pk/19-Nov-2018/educational-system-of-pakistan

13. http://www.ips.org.pk/fourth-industrial-revolution-implications-pakistan/ 